\title{
Evaluation on the Supplier Management in the Supply Chain Management Environment
}

\author{
Wang Xiaobin \\ School of Economic and Management \\ Shenyang Aerospace University \\ Shenyang China
}

\author{
Peng Yingtao \\ School of Economic and Management \\ Shenyang Aerospace University \\ Shenyang China
}

\begin{abstract}
Along with the progressing of technology and developing of the economy, the forming of the global information system and the global market and the accelerating of the technology transform, technology progressing and the diversification make the life cycle of products more and more shortened, enterprises are facing with the pressure of shortening the delivery, improving product quality, depressing the cost and improving on service. To strengthen the competition of enterprises, the method of supplier synthetically evaluation and selection has been a key factor to decide whether the supply chain would be successful or not, especially when Supply Chain (SC) has been developed into a multiple tasks and relationship network.
\end{abstract}

Key words: Supply Chain; Evaluation Index System; Analytic Hierarchy Process

\section{INTRODUCTION}

Supplier selection and management is a hot topic in the research on supply chain management. Suppliers as the source of supply chain have an important impact on the customer demand responsiveness, product quality, product cost and innovation ability and so on of the supply chain and become an important part of the decision-making in a supply chain. Scientifically selecting suppliers is an important condition to maintain the competitiveness of the supply chain. Aiming at improving the competitiveness of the supply chain in speed, quality, cost and innovation, establish the factors that influence supplier selection, set up a reasonable suppliers evaluation and selection indicator system for different types of suppliers and select suppliers with scientific methods. These are the major problems in the supplier management of enterprises in the supply chain environment.

\section{THE SUPPLY CHAIN AND SUPPLIER EVALUATION AND SELECTION OVERVIEW}

This paper concerns the field of supply chain involved in this paper, and main problem to be solved is to explore how enterprises should build supply chains based the supplier evaluation indicator system. Therefore, relevant theories of the supply chain is first introduced in this Chapter.

\section{A. Relevant concepts of supply chain management}

Supply Chain Management (abbreviated as SCM) has become a widely used business management mode in the highly competitive global economic environment. Supply chain management is the planning, organization, coordination and control of the logistics, information flow, capital flow, value stream and workflow in the supply chain, to establish strategic partnership between the supply, production and marketing enterprises and customers to reduce internal loss and waste and optimize the overall efficiency and effectiveness of the supply chain.

\section{B. The processes and procedures of supplier selection}

Determine the procedures for the implementation of supply chain management to help node enterprises in the supply chain clear about what they should do and when they should take action in supply chain management. This allows the supply chain management follow the prescribed order, to avoid repetitive work. This work follows the steps shown below in Figure .1.

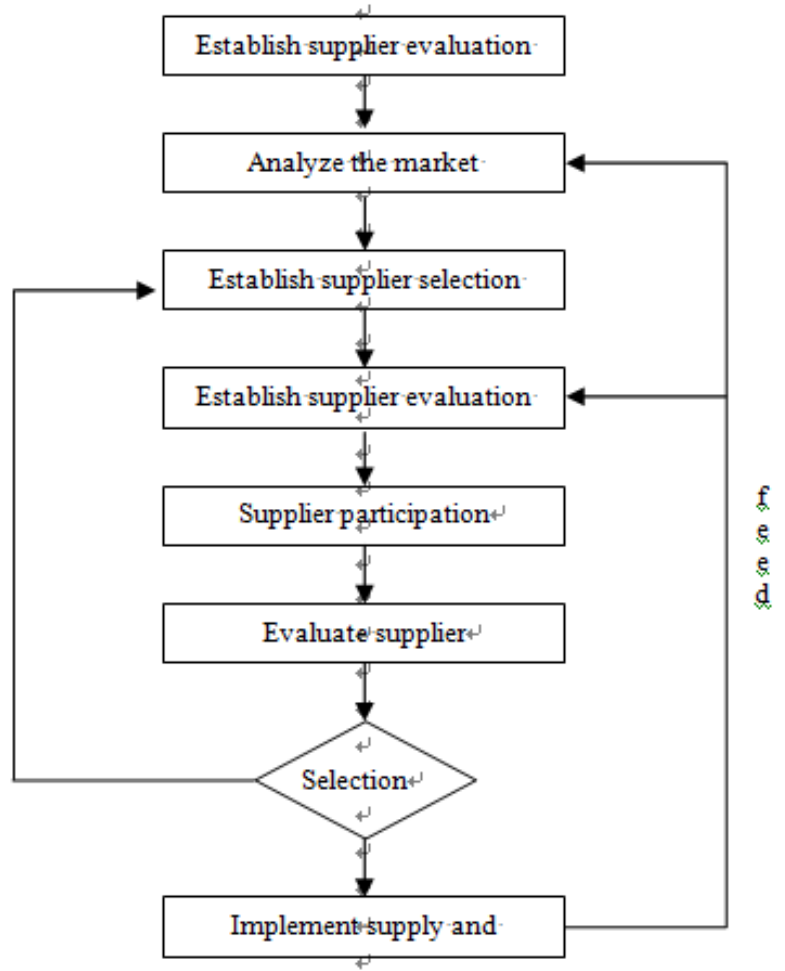

Figure.1 vendor selection processes and procedures

\section{Methods of supplier selection in supply chain management environment}

There are many methods for supplier evaluation and selection, which are generally chosen based on the number 
of suppliers, the level of understanding of the suppliers as well as whether the demand for materials is urgent or not.

Many methods have been presented to carry out supplier evaluation and selection, and the advantages and disadvantages and the application range of several evaluation methods are listed in the following table.1.

TABLE I THE APPLICATION OF SEVERAL EVALUATION METHODS

\begin{tabular}{|c|c|c|c|}
\hline $\begin{array}{l}\text { Evaluation } \\
\text { Mediced }\end{array}$ & Advantige & Dlaadvamuge: & $\begin{array}{l}\text { Application } \\
\text { Edicators. }\end{array}$ \\
\hline $\begin{array}{l}\text { Public iender } \\
\text { method }\end{array}$ & $\begin{array}{l}\text { Highly conpetitive, } \\
\text { sabiafactory ruply price } \\
\text { and supply services gor } \\
\text { bougb comparison. }\end{array}$ & $\begin{array}{l}\text { Hard to evaluast the } \\
\text { comporite repueatian and } \\
\text { production managrment } \\
\text { potential rupply risks: }\end{array}$ & $\begin{array}{l}\text { Xhin bo evaluate die. } \\
\text { indicance of price factor. }\end{array}$ \\
\hline $\begin{array}{l}\text { Negodned } \\
\text { Settlement: }\end{array}$ & $\begin{array}{l}\text { Pacesu is simple, esp } \\
\text { to opernet }\end{array}$ & $\begin{array}{l}\text { Getuly in fluraced by } \\
\text { hummin factoss, not quire } \\
\text { scientific; potential risk }\end{array}$ & 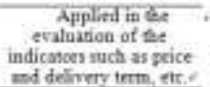 \\
\hline $\begin{array}{l}\text { Judsed by } \\
\text { appeinate. }\end{array}$ & $\begin{array}{l}\text { Reduce walustion } \\
\text { cunts: }\end{array}$ & 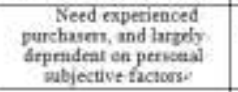 & $\begin{array}{c}\text { Avalate for } 2 \\
\text { variety of qualitasive: } \\
\text { ledieatars: }\end{array}$ \\
\hline $\begin{array}{c}\text { Expers } \\
\text { sosering methode }\end{array}$ & 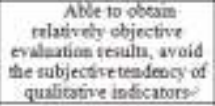 & $\begin{array}{l}\text { Need more conplicated } \\
\text { ptocesses, increasiag the } \\
\text { evaluation cost }\end{array}$ & $\begin{array}{l}\text { Available for vations } \\
\text { qualinative evilaatian } \\
\text { bedicators: }\end{array}$ \\
\hline $\begin{array}{l}\text { Procurement } \\
\text { cost comparison } \\
\text { mirtiod }\end{array}$ & $\begin{array}{l}\text { Get lower prices and } \\
\text { transsction contr }\end{array}$ & $\begin{array}{l}\text { Sor coaventient for the } \\
\text { operation on qualinative } \\
\text { ieficatars }\end{array}$ & $\begin{array}{l}\text { For the indicisose } \\
\text { relnted to price and } \\
\text { tantaction couts. }\end{array}$ \\
\hline $\begin{array}{l}\text { Linear } \\
\text { weighting } \\
\text { method }\end{array}$ & $\begin{array}{c}\text { Pelutively } \\
\text { compentiesive, assigning } \\
\text { weights, imvolving 2 } \\
\text { varinty of key =dicatum }\end{array}$ & $\begin{array}{l}\text { Weight distibutice has } \\
\text { so be scietific and rational }\end{array}$ & $\begin{array}{l}\text { Fer the evaluation of } \\
\text { the indicators such as } \\
\text { price and rervice etr. }\end{array}$ \\
\hline $\begin{array}{c}\text { Menti- } \\
\text { objective } \\
\text { matiematical } \\
\text { planniat } \\
\text { method }\end{array}$ & $\begin{array}{l}\text { More teasonsthe tesn } \\
\text { the linear wripiting } \\
\text { methos }\end{array}$ & $\begin{array}{c}\text { Deficult to dassify } \\
\text { diaperied typer of rupplien }\end{array}$ & $\begin{array}{l}\text { For the relevant } \\
\text { evaluation of } \\
\text { quantuative indicases: }\end{array}$ \\
\hline $\begin{array}{l}\text { Amalytic } \\
\text { Hierarcby } \\
\text { Procenat }\end{array}$ & $\begin{array}{l}\text { Scirntilicic tational and } \\
\text { deavi }\end{array}$ & Tedionas: & $\begin{array}{l}\text { Avaliske for: } \\
\text { variety of quastivive } \\
\text { idicators }\end{array}$ \\
\hline
\end{tabular}

III. THE CONSTRUCTION OF SUPPLIER EVALUATION INDICATOR SYSTEM IN SUPPLY CHAIN MANAGEMENT ENVIRONMENT

In the supply chain environment, the major enterprises not only present higher demands for product quality, delivery and price, but also for the suppliers' strategies, operation, cooperative reputation and construction of information system accordingly. Moreover, the supplier evaluation indicator system is the premise of fairly and properly selecting suppliers, so the proper construction of the supplier evaluation indicator system has great theoretical and practical significance.

\section{A. Design principles of supplier evaluation indicator system}

1. The comprehensive principle. A comprehensive evaluation of suppliers must be based on the evaluation of various factors that influence the actual management efficiency and operation performance, as well as the full consideration of those factors that can affect the collaboration of enterprises in the supply chain (for example, enterprise culture), to design reasonable supplier evaluation indicator system and indicator content according to the actual situation of China.

2. The operable principle. No matter how perfect an evaluation indicator system is, operational faults are also easy to occur in actual operation. Therefore, the simple and convenient operation of the evaluation indicators shall be guaranteed, in order to improve working efficiency, so that it will be more convenient and easy for the decisionmakers to make decisions.

3. The adaptive principle. The evaluation indicator system of suppliers shall be widely adaptive, not restricted by the factors like enterprise scale etc, and the evaluation methods, content and system can be well applied to any business.

\section{B. The weight setting method of supplier evaluation system}

Weight is an important part of the construction of the evaluation indicator system, and a reasonable allocation of weight is the key to the comprehensive evaluation of the evaluation indicator system. Therefore, whether the weight of the evaluation indicator system is set in a scientific and accurate way will seriously affect the result of comprehensive evaluation.

According to the different sources of the original data in the calculation of weight, the methods of determining the weight of indicators can be classified into two categories: one is the subjective assignment method, such as the Delphi method. The other is objective assignment method, such as gray relational analysis. Below are the principles and the advantages and disadvantages of these methods introduced respectively.

\section{1) Delphi method}

This is the most commonly used method, which is an investigation method to analyze, judge, weigh and attach corresponding weight to the prescribed evaluation indicators, according the knowledge, wisdom, experience, information and values of a number of experts.

The method is available for a wide range of application, not restricted by whether there is data limitation, and the disadvantages are: (1) influenced by subjective factors such as expert knowledge and experience. (2) Experts answer back to back may result in the situation of relatively low consistency coefficient. (3) Without a precision indicator, it is not clear whether the accuracy is improved after the re-estimation of weight.

TABLE II SUPPLIER EVALUATION INDICATOR HIERARCHY CHART

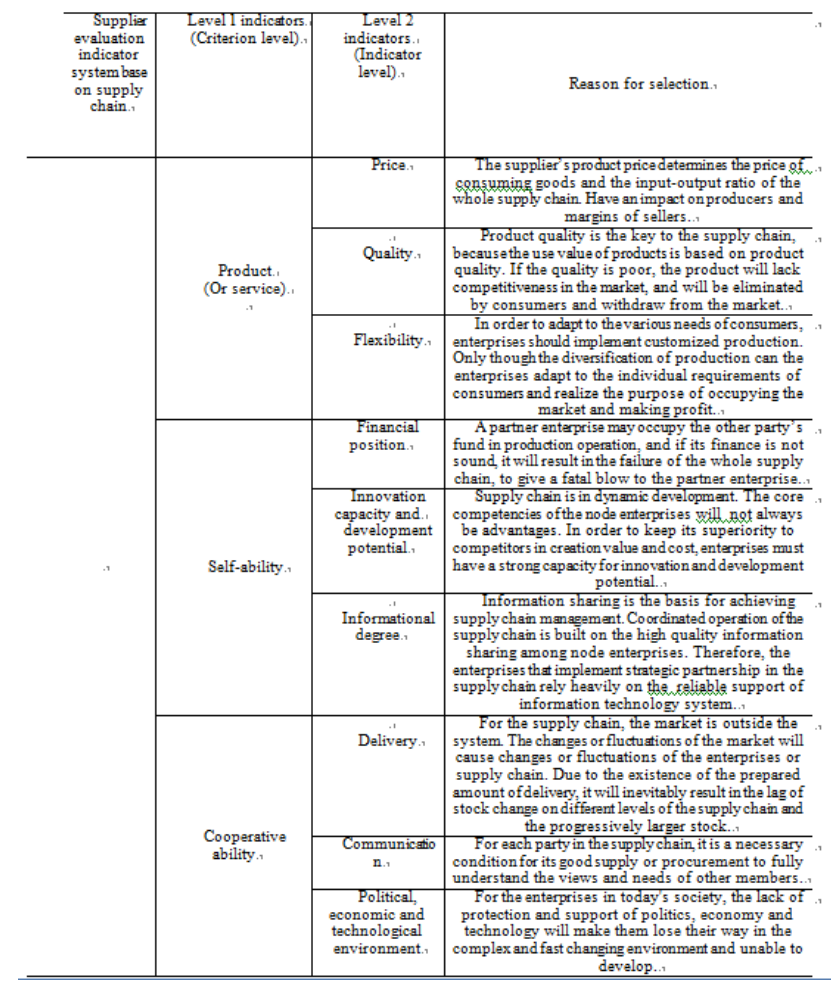




\section{2) Gray relational analysis}

This approach reflects the degree of association between things in development, and the system is regarded as a developing and changing system, for the quantitative analysis of the development trend of this dynamic process.

The method requires less sample data for calculation and less calculation and with this method, highly accurate results can be obtained. The disadvantage is the need of sample data and its time sequence characteristic.

\section{THE CONSTRUCTION AND APPLICATION OF SUPPLIER EVALUATION INDICATOR SYSTEM BASED ON ANALYTIC HIERARCHY PROCESS}

\section{A. The reason for using the analytic hierarchy process to select suppliers}

Supplier selection is a multi-attribute decision making issue, so we must consider multiple criteria when making selections, such as "practicality, accuracy, fairness, reliability, effectiveness, systematic property" and so on. Thus, if compared only in terms of a single criterion, the comprehensive effectiveness and advantages and disadvantages of the decision making methods cannot be shown.

\section{B. To determine the supplier evaluation indicator system based on analytic hierarchy process}

\section{1) Principle of the analytic hierarchy process}

In essence, the analytic hierarchy process is the formalization of human beings' understanding of the hierarchical structure of complex issues, and as it is practical, concise and systemic, it attracts wide attention and is quickly applied to the multi-attribute decision issues in various fields. The key point in the application of analytic hierarchical process in multi-attribute decision is to make it possible for the decision makers to use attribute hierarchy structure visually to construct complex multiattribute decision making problems.

2) The reference indicators in the framework of supplier evaluation indicator system

Though the determination of supplier evaluation indicators is related to specific procurement requirements, by summarizing the current supply chain management practice of relevant enterprises and scholars at home and abroad, the selection evaluation indicators for a supplier is composed of four major aspects. Supplier evaluation indicator hierarchical chart is shown below in Table .3:

TABLE III PERFORMANCE EVALUATION LEVEL 1 INDICATORS JUDGMENT MATRIX

\begin{tabular}{|c|c|c|c|c|c|}
\hline י. & $\begin{array}{l}\text { Product. } \\
\text { (Or } \\
\text { service).. }\end{array}$ & $\begin{array}{l}\text { Self- } \\
\text { ability.. }\end{array}$ & $\begin{array}{l}\text { Cooperativ } \\
\text { e ability. }\end{array}$ & $\begin{array}{c}\text { Sustainable } \\
\text { Development. } \\
\text { Ability.. }\end{array}$ & Weight. \\
\hline $\begin{array}{l}\text { Product (or } \\
\text { service). }\end{array}$ & 1.1 & $1 .$. & 2.1 & 29.9. & 0.345 \\
\hline Self-ability. 1 & 1.1. & 1.1 & 2.1 & 20.2. & 0.370 .1 \\
\hline $\begin{array}{l}\text { Cooperative } \\
\text { ability. }\end{array}$ & $1 / 2.1$ & $1 / 2$. & 1.1 & 15.4. & 0.185. \\
\hline $\begin{array}{l}\text { Sustainable } \\
\text { development } \\
\text { ability., }\end{array}$ & $1 / 3$. & $1 / 4$. & $1 / 2.1$ & 11.6. & 0.100. \\
\hline
\end{tabular}

3) The weight setting of the supplier evaluation indicator system

On the basis of the supplier evaluation indicator hierarchy structure chart completed, the analytic hierarchy process is adopted for the weight setting of indicators on all levels. The first step is to obtain pair judgment matrix of indicators on all levels through questionnaire survey; the second step is the calculation of weight and the determination of consistency. Finally we get the indicators on all levels and their weight, as shown in the following tables (Table .4-Table .8):

TABLE IV PRODUCTS (OR SERVICES) INDICATORS JUDGMENT MATRIX

\begin{tabular}{|c|c|c|c|c|}
\hline$\because$ & Price.1 & Quality. & Flexibility. & Weight. \\
\hline Price.1 & 1.1 & 2.1 & $1 / 3$. & 0.230 \\
\hline Quality.r & $1 / 2.1$ & 1.1 & $1 / 5$. & 0.122. \\
\hline Flexibility. & 3.1 & 5.1 & 1.1 & 0.648 \\
\hline
\end{tabular}

TABLE V SELF-ABILITY INDICATOR JUDGMENT MATRIX

\begin{tabular}{|c|c|c|c|c|}
\hline$\because$ & $\begin{array}{c}\text { Financial } \\
\text { position. }\end{array}$ & $\begin{array}{l}\text { Innovation } \\
\text { capacity and } \\
\text { development } \\
\text { potential. }\end{array}$ & $\begin{array}{l}\text { Informational } \\
\text { degrea. }\end{array}$ & Weight. \\
\hline Financial position. & 1.1. & 2.1 & $1 / 3$. & 0.230 \\
\hline $\begin{array}{l}\text { Innovation } \\
\text { capacity and } \\
\text { development } \\
\text { potential. }\end{array}$ & $1 / 2$. & 1.1 & $1 / 5$. & 0.122. \\
\hline $\begin{array}{l}\text { Informational } \\
\text { degree. }\end{array}$ & 3.1 & 5.7 & 1.9 & 0.648. \\
\hline
\end{tabular}

TABLE VI COOPERATIVE CAPACITY INDICATORS JUDGMENT MATRIX

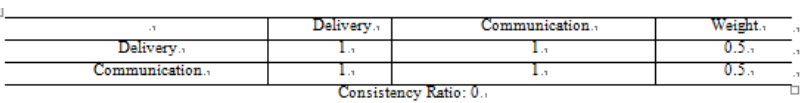

TABLE VII SUSTAINABLE DEVELOPMENT INDICATORS JUDGMENT MATRIX

\begin{tabular}{c|c|c|c}
\hline & $\begin{array}{c}\text { Corporate } \\
\text { culture.r }\end{array}$ & $\begin{array}{c}\text { Political, economic and } \\
\text { technological environment.. }\end{array}$ & Weight.r \\
\hline Corporate culture.r & 1.1 & 3.1 & 0.75 .1 \\
\hline $\begin{array}{c}\text { Political, economic and } \\
\text { technological environment.r }\end{array}$ & $1 / 3.1$ & 1.1 & 0.25 .1 \\
\hline \multicolumn{4}{|c|}{ Consistency Ratio: 0.1}
\end{tabular}

TABLE VIII SUPPLIER PERFORMANCE EVALUATION INDICATORS WEIGHT LIST

\begin{tabular}{|c|c|c|c|c|c|}
\hline \multirow{6}{*}{$\begin{array}{l}\quad \text { Supplier } \\
\text { performance } \\
\text { evahuation } \\
\text { indicators } \\
\text { weight list. }\end{array}$} & \multicolumn{2}{|c|}{ Level 1 indicators.r. } & \multicolumn{2}{|c|}{ Level 2 indicators. } & \multirow{2}{*}{$\begin{array}{l}\begin{array}{c}\text { Combining } \\
\text { weights.1 }\end{array} \\
\qquad .\end{array}$} \\
\hline & Indicator & Scores. & Indicators .1 & Scores.1 & \\
\hline & \multirow{3}{*}{$\begin{array}{c}\text { Procuct } \\
\text { (or service) }\end{array}$} & \multirow{3}{*}{0.345} & Quality. & 0.230. & 0.079. \\
\hline & & & Price.r & 0.122. & 0.042 .7 \\
\hline & & & Flexibility. & 0.648 & 0.224. \\
\hline & Self- & 0.370 & $\begin{array}{c}\text { Financial } \\
\text { position. }\end{array}$ & 0.230. & 0.085. \\
\hline
\end{tabular}

\section{CONCLUSION}

This paper focuses on the theme of supplier evaluation and selection by enterprises in the supply chain environment. Based on the existing research results, the problems in the supplier management of enterprises, the selection of suppliers by enterprises is elaborated, which is started from the supplier evaluation indicator system in supply chain environment, with the factors to be considered in the selection of suppliers as the research focus. By combining the analytic hierarchy process, it is an aim to find a method for a comprehensive analysis and evaluation of suppliers and to provide theoretical guidance 
for the practical evaluation and selection of suppliers by enterprises.

\section{REFERENCES}

[1] Ma Shihua, Lin Yong. Supply Chain Management (Second Edition) [M]. Beijing: China Machine Press, 2005.

[2] Donald J Bowersox. Supply Chain Logistics Management [M]. Beijing: China Machine Press, 2004.

[3] Zhang Guhai. Research on the supplier selection in supply chain management. Shanghai: Tongji University, 2007, 120-127.

[4] Chen Chunming. Research on Supplier Evaluation Indicator System, Learning and Exploration, 2005, 12 (4) :197-201.

[5] Lu Yong. Build a comprehensive supplier evaluation system, Value Engineering, 2004, 12 (3) : 55-57.
[6] Hong Weimin, Liu Jin. Summary of Performance Evaluation of Supply Chain, Business Studies, 2006, 8:17-20.

[7] Huo Jiazhen. Integrated Supply Chain Performance Evaluation System and Its Application, Beijing: Tsinghua University Press, 2005.

[8] Huo Jiazhen, Lei Xinghui, Sui Minggang. Research on the supply chain performance evaluation system based on supply chain, Journal of Shanghai University, 2004, 8 (4) :177-189.

[9] Guan Zhimin, Supplier Selection Method and Its Application in the Supply Chain Environment, Shenyang: Northeastern University, 2006.

[10] Sunil Chopra, Peter Meindl. Supply Chain Management-Strategy, Planning, and Operation, Beijing: Tsinghua University Press, 2001, 4-5. 